\section{En utrolig historie}

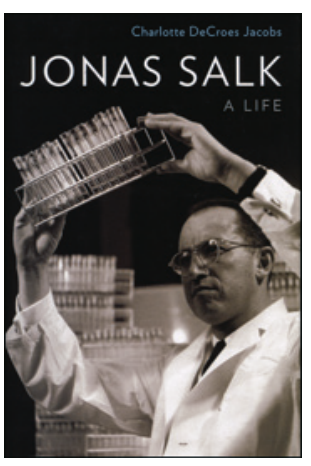

Charlotte DeCroes Jacobs

Jonas Salk

A life. 559 s, ill. Oxford: Oxford University

Press, 2015. Pris GBP 23

ISBN 978-0-19-933441-4
12. april 1955 fant det sted en medisinsk pressekonferanse i USA som verden aldri før eller siden har sett maken til. Hele Amerika satt klistret til radioen for å høre at «polio is conquered». Den største epidemiologiske undersøkelsen i medisinens historie hadde klart vist at Salks drepte vaksine beskyttet mot poliomyelitt.

Ved slutten av første verdenskrig hadde spanskesyken tatt livet av 20 millioner mennesker, nesten én million bare i USA. I 1940og 50-årene i USA var frykten for polio nesten like stor som frykten for atomkrig.

Forfatteren av denne omfattende og grundige biografien, Charlotte Jacobs, har tidligere vært professor i medisin ved Stanford. Hun skildrer ikke bare en kontroversiell mann, men gir også bildet av sider ved forrige århundres amerikanske medisinske forskning.

I den første delen beskrives Jonas Salks (1914-95) tidlige liv, utdanning og forskning og gjennombruddet for hans poliovaksine. Allerede som tenåring følte han at han hadde en stor oppgave i livet - å hjelpe syke, forebygge sykdom og arbeide for et mer menneskeverdig samfunn. Mens andre forskere var opptatt med å utvikle en levende virusvaksine mot polio, var Salk engasjert i arbeidet med en drept vaksine. I 1954 sponset Foundation for Infantile Paralysis, som hadde gitt betydelig støtte til Salks forskning gjennom flere år, et omfattende dobbeltblindt forsøk med hans vaksine. Nesten to millioner skolebarn fra hele USA, 220000 leger og helsearbeidere, 40000 sykepleiere, 14000 lærere og over 200000 frivillige deltok. Etter at Salks vaksine hadde dokumentert sin forebyggende virkning, ble Jonas Salk dagens helt. Da han ble æret under en seremoni i Det hvite hus, var det en gråtkvalt president Dwight D. Eisenhower som takket.

I den andre delen skildres Salks tilbakegang etter suksessen i 1955. Salk ble nå mer og mer opptatt av filosofiske problemer og fikk bygd et praktfullt institutt ved San Diego som skulle være en brobygger mellom naturvitenskap og humaniora. Det gikk ikke lang tid før instituttet tiltrakk seg nobelprisvinnere og andre berømte forskere fra hele verden. Men Salks egen forskning begynte nå å kjede ham. Han hoppet over på kreft og multippel sklerose og ble siden også opptatt med AIDS og utvikling av en drept vaksine mot denne sykdommen, noe som også endte med skuffelse. Samtidig fikk hans rival Albert Sabin mer og mer oppslutning om sin levende poliovaksine.

Salks institutt utviklet seg på det vitenskapelige plan, men rollen som pådriver innen humaniora avtok etter hvert og ble av mange biologer sett på som latterlig. På det personlige plan skjedde det også store endringer. Han skilte seg fra sin begavede kone etter 30 års ekteskap og giftet seg med kunstmaleren Françoise Gilot, best kjent som Picassos elskerinne. Han begynte å skrive bøker om vitenskap og kultur, praktiserte yoga og hadde kontakt med flere kvinner der han også fikk diskutert sine bokprosjekter.

Men verst av alt for Salk personlig var at han selv ble gradvis presset ut av sitt eget institutt og til slutt satt bare tilbake som «founding director» uten laboratorieplass og forskningsmidler. Etter noen år ble også Salks drepte vaksine i mange land erstattet med Sabins levende vaksine. Men Salk arbeidet samtidig målbevisst for å gjøre sin egen vaksine mot polio mer potent, og i 1999 gikk USA tilbake til hans vaksine. Salk levde imidlertid ikke lenge nok til å få oppleve denne seieren.

Dette er en glimrende biografi, interessant og godt skrevet. Den kan leses av alle, ikke bare medisinere. Boken gir et fascinerende bilde av en særpreget forsker og viser også hvordan sjalusi og misunnelse kan prege det vitenskapelige samfunn.

Svakheter? Forfatteren nevner ikke den antisemittiske holdningen ved amerikanske universiteter i 1930-årene. Salk, selv jøde, begynte å studere medisin ved New York University, det eneste universitetet som, i motsetning til Yale, Harvard, Columbia og andre, ikke hadde noen «jødisk kvote». Forfatteren nevner heller ikke Salks politiske støtte til Physicians for social responsibility og andre liberale organisasjoner som fikk Hoovers FBI til å interessere seg for Salk.

\section{Einar Kringlen}

Professor

Psykiatrisk institutt, Vinderen, Universitetet i Oslo 